\title{
RASIONALITAS PENGGUNAAN ANTIBIOTIK DALAM PENGOBATAN DEMAM TIFOID DI RUMAH SAKIT X TAHUN 2020
}

\author{
Mayaranti Wilsya ${ }^{1}$, Yunilda Rosa ${ }^{2 *}$, Dian P.F. ${ }^{3}$ \\ 1,2,3. Program Study SI Farmasi STIK Siti Khadijah Palembang \\ Email $^{2 *}$ : yunildarosa2018@gmail.com
}

\begin{abstract}
ABSTRAK
Demam tifoid adalah infeksi sistemik yang disebabkan bakteri Salmonella typhi, biasanya melalui konsumsi makanan atau air di lingkungan yang terkontaminasi. Penyakit akut ditandai oleh demam berkepanjangan, sakit kepala, mual, kehilangan nafsu makan dan sembelit atau kadang-kadang diare. Penggunaan antibiotik secara rasional adalah pemberian antibiotik yang sesuai dengan indikasi, tepat dosis, tepat lama pemberian obat, tepat interval obat, aman dan terjangkau. Tujuan penelitian ini adalah untuk mengevaluasi rasionalitas penggunaan antibiotik pada pasien demam tifoid di RS X periode Januari-Desember 2020. Penelitian kualitatif menggunakan rancangan penelitian noneksperimental yang bersifat deskriptif. Pengambilan data sacara retrospektif dari rekam medis pasien demam tifoid yang menerima antibiotik di RS X periode Januari-Desember 2020. Rasionalitas penggunaan antibiotik dianalisis dengan menggunakan metode Gyssens. Hasil analisis rasionalitas penggunaan antibiotik pada pasien demam tifoid yang menjalani rawat inap di RS X periode JanuariDesember 2020 dari 80 rekam medis pasien, terdapat $90 \%$ penggunaan terapi antibiotik rasional dan terdapat $10 \%$ yang tidak rasional termasuk pada ketegori I-VI penggunaan antibiotik tidak rasional termasuk (kategori IVA) ada antibiotik lain yang lebih efektif sebesar 3,75\%, (kategori IIIB) waktu pemberian antibiotik terlalu singkat dari waktu terapi yang sebenarnya sebesar $6,25 \%$.
\end{abstract}

Kata kunci : Antibiotik, Rasional, Gyssens

\begin{abstract}
Typhoid fever is a systemic infection caused by Salmonella typhi bacteria, usually through the consumption of food or water in a contaminated environment. Acute illness is characterized by prolonged fever, headache, nausea, loss of appetite and constipation or sometimes diarrhea. Rational use of antibiotics is the administration of antibiotics that are in accordance with indications, appropriate dosage, appropriate length of drug administration, appropriate drug interval, safe and affordable. The aim of this study was to evaluate the rationality of antibiotic use in typhoid fever patients in HOSPITAL X in the period January-December 2020. Qualitative research uses nonexperimental research designs that are descriptive in nature. The collection of retrospective data from the medical records of typhoid fever patients who received antibiotics in HOSPITAL X in the period January-December 2020. The rationality of antibiotic use was analyzed using the Gyssens method. The results of the rationality analysis of antibiotic use in typhoid fever patients who undergo hospitalization in Hospital X period January-December 2020 from 80 patient medical records, there are $90 \%$ use of rational antibiotic therapy and there are 10\% that are irrational including in the theory of I-VI irrational antibiotic use including (category IVA) there are other antibiotics that are more effective as $3.75 \%$, (category IIIB) the time of antibiotic administration is too short than the actual therapy time $6.25 \%$
\end{abstract}

Keywords: Antibiotics, Rational, Gyssens 


\section{PENDAHULUAN}

Tifoid merupakan salah satu penyakit endemis yang ada di Indonesia. Mayoritas mengenai anak usia sekolah dan kelompok usia produktif, penyakit ini menyebabkan angka absensi yang tinggi (Kemenkes RI, 2018). Demam tifoid adalah infeksi sistemik yang disebabkan oleh bakteri Salmonella typhi, biasanya melalui konsumsi makanan atau air di lingkungan yang terkontaminasi. Penyakit akut ditandai oleh demam berkepanjangan, sakit kepala, mual, kehilangan nafsu makan, dan sembelit atau kadang-kadang diare. Gejala seringkali tidak spesifik dan secara klinis tidak dapat dibedakan dari penyakit demam lainnya (WHO, 2018).

Pengobatan pada demam tifoid dapat dilakukan dengan terapi non-farmakologi yaitu dengan melakukan tirah baring, diet lunak rendah serat dan menjaga kebersihan. Lalu pengobatan lainnya dengan terapi farmakologi yaitu dengan penggunaan obat antibiotik seperti ampicillin / amoxycillin trimethoprim /sulfamethoxazole, chloram phenicol, ciprofloxacin, ofloxacin, cefixime, azitthromycin dan ceftriaxone (WHO, 2019).

Penggunaan obat antibiotik berbeda dengan pemberian jenis obat-obatan yang lainnya, selain harus memperhatikan pasien dan obat kita juga harus memperhatikan karakteristik dari infeksi yang akan ditangani. Untuk mencapai tujuan terapi yang optimal antibiotik harus digunakan serasional mungkin. Penggunaan antibiotik yang rasional harus didasari dengan pemahaman terhadap beberapa aspek dari penyakit infeksi terkait dan memperhatikan beberapa faktor seperti ketahanan individu, virulensi, mikroorganisme serta farmakokinetik dan farmakodinamis dari antibiotik yang akan digunakan. Dampak terbesar akibat penggunaan antibiotik yang tidak rasional adalah berkembangnya kuman-kuman resisten antibiotik (Gyssen, 2015).

Penggunaan obat dikatakan rasional jika memenuhi kriteria seperti tepat diagnosis, tepat indikasi penyakit, tepat pemilihan obat, tepat dosis, tepat cara pemberian, tepat interval waktu pemberian, tepat lama pemberian, waspada terhadap efek samping, tepat penilaian kondisi pasien, obat yang diberikan harus efektif dan aman dengan mutu terjamin serta tersedia setiap saat dengan harga yang terjangkau, tepat informasi, tepat tindak lanjut (follow-up), tepat penyerahan obat (dispensing) dan pasien patuh terhadap perintah pengobatan yang dibutuhkan (Kemenkes, 2011).

Menurut Tandi, J. (2017), yang melakukan kajian Rasionalitas Penggunaan Obat Pada Kasus Demam Tifoid Di Instalasi Rawat Inap Anutaputra Palu , didapat hasil bahwa persentase penggunaan obat berdasarkan tepat dosis yang sesuai adalah $82,22 \%$, persentase penggunaan obat berdasarkan tepat indikasi yang sesuai adalah $100 \%$, persentase interaksi obat $100 \%$ tidak terjadi interaksi obat dan persentase efek samping juga $100 \%$ tidak ada keluhan efek samping yang tidak diharapkan dari obat.

\section{METODE PENELITIAN}

\section{Populasi}

Populasi dalam penelitian adalah 271 pasien demam tifoid yang tercatat di rekam medis instalasi rawat inap RS X

\section{Sampel}

Sampel yang digunakan adalah pasien demam tifoid yang tercatat di rekam medik instalasi rawat inap RS X periode JanuariDesember tahun 2020. Dalam pengambilan sampel penelitian dilakukan dengan metode purposive sampling.

\section{Prosedur Penelitian}

Pengambilan sampel menggunakan metode purposive sampling. Pengumpulan data dilakukan dengan mencatat data-data yang dibutuhkan peneliti seperti umur, jenis kelamin, bobot tubuh, tepat diagnosis, tepat indikasi, tepat pemilihan obat, tepat dosis, tepat cara pemberian, tepat interval waktu 
pemberian dan tepat lama pemberian pada pasien demam tifoid di instalasi rawat inap berdasarkan dari data rekam medis di RS X Data yang dkumpulkan kemudian dianalisis secara deskriptif.

\section{Analisi Data}

Dalam penelitian ini data dianalisis secara deskriptif dan disajikan dalam bentuk tabel. Penggunaan metode deskriptif dengan tujuan untuk memperoleh gambaran pola pengobatan demam tifoid pada pasien instalasi rawat inap di RS X.

\section{HASIL PENELITIAN}

Subjek yang berpartisipasi dalam penelitian ini sebanyak 80, dengan karakteristik seperti disajikan pada tabel 1 .

Tabel 1. Karakteristik penderita demam tifoid berdasarkan umur dan jenis kelamin

\begin{tabular}{|l|l|c|c|}
\hline No & $\begin{array}{l}\text { Karakteristik } \\
\text { Pasien }\end{array}$ & Jumlah & $\begin{array}{c}\text { Persentase } \\
(\%)\end{array}$ \\
\hline 1. & Umur & 40 & $51 \%$ \\
& $17-25$ Tahun \\
& 26-35 Tahun & 17 & $21 \%$ \\
& 36-45 Tahun & 10 & $12 \%$ \\
& 46-55 Tahun & 9 & $11 \%$ \\
& $56-65$ Tahun & 4 & $5 \%$ \\
\cline { 2 - 4 } & Total & $\mathbf{8 0}$ & $\mathbf{1 0 0}$ \\
\hline 2. & Jenis Kelamin & 34 & $42 \%$ \\
& Laki-laki & 46 & $58 \%$ \\
& Perempuan & & \\
\cline { 2 - 4 } & Total & $\mathbf{7 3}$ & $\mathbf{1 0 0} \%$ \\
\hline
\end{tabular}

Subjek yang berpartisipasi dalam penelitian ini sebanyak 80 , dengan pola penggunaan obat antibiotik pada pasien demam tifoid seperti disajikan pada tabel tabel 2.
Tabel 2. pola penggunaan obat antibiotik pada pasien demam tifoid

\begin{tabular}{|c|c|c|}
\hline Karakteristik & Jumlah & Persentase \\
\hline $\begin{array}{cl}\text { Jenis } & \text { Antibiotik } \\
\text { 1. } & \text { Ceftriaxone } \\
\text { 2. } & \text { Cefepime } \\
\text { 3. } & \text { Cefixime }\end{array}$ & $\begin{array}{c}72 \\
6 \\
2\end{array}$ & $\begin{array}{c}90 \% \\
7 \% \\
3 \%\end{array}$ \\
\hline Total & 80 & $100 \%$ \\
\hline $\begin{array}{l}\text { Rute Pemberian } \\
\text { 1. Intravena } \\
\text { 2. Oral }\end{array}$ & $\begin{array}{c}78 \\
2\end{array}$ & $\begin{array}{c}97 \% \\
2 \%\end{array}$ \\
\hline Total & 80 & $100 \%$ \\
\hline
\end{tabular}

Subjek yang berpartisipasi dalam penelitian ini sebanyak 80, dengan hasil evaluasi ketepatan penggunaan antibiotik pasien demam tifoid dengan metode Gyssens seperti disajikan pada table 3.

Tabel 3. Hasil evaluasi ketepatan penggunaan antibiotik pasien demam tifoid dengan metode Gyssens

\begin{tabular}{|l|l|l|}
\hline $\begin{array}{l}\text { Kategori Kerasionalan Dg } \\
\text { Metode Gyssens }\end{array}$ & Jumlah & Persen (\%) \\
\hline Kategori VI & 0 & $0 \%$ \\
\hline Kategori V & 0 & $0 \%$ \\
\hline Kategori IVA & 3 & $3,75 \%$ \\
\hline Kategori IVB & 0 & $0 \%$ \\
\hline Kategori IVC & 0 & $0 \%$ \\
\hline Kategori IVD & 0 & $0 \%$ \\
\hline Kategori IIIA & 0 & $0 \%$ \\
\hline Kategori IIIB & & 5 \\
\hline Kategori IIA & 0 & $6,25 \%$ \\
\hline Kategori IIB & 0 & $0 \%$ \\
\hline Kategori IIC & 0 & $0 \%$ \\
\hline Kategori I & 0 & $0 \%$ \\
\hline Kategori 0 & 72 & $90 \%$ \\
\hline Total & 80 & $100 \%$ \\
\hline
\end{tabular}

Katerangan :

Kategori $0 \quad$ : Penggunaan antibiotik tepat/bijak

Kategori I : Penggunaan antibiotik tidak tepat waktu

Kategori IIA : Penggunaan antibiotik tidak tepat dosis 


\begin{tabular}{|c|c|}
\hline Kategori IIB & \\
\hline & interval \\
\hline Kategori IIC & $\begin{array}{l}\text { Penggunaan antibiotik tidak } \\
\text { tepat cara/rute pemberian }\end{array}$ \\
\hline Kategori IIIA & $\begin{array}{l}\text { Penggunaan antibiotik terlalu } \\
\text { lama }\end{array}$ \\
\hline Kategori IIIB & $\begin{array}{l}\text { : Penggunaan antibiotik terlalu } \\
\text { singkat }\end{array}$ \\
\hline Kategori IVA & $\begin{array}{l}\text { Ada antibiotik lain yang lebih } \\
\text { efektif }\end{array}$ \\
\hline Kategori IVB & $\begin{array}{l}\text { : Ada antibiotik lain yang } \\
\text { kurang toksik/lebih aman }\end{array}$ \\
\hline Kategori IVC & $\begin{array}{l}\text { : Ada antibiotik lain yang lebih } \\
\text { murah }\end{array}$ \\
\hline Kategori IVD & $\begin{array}{l}\text { : Ada antibiotik lain yang } \\
\text { spektrumnya lebih sempit }\end{array}$ \\
\hline Kategori V & $\begin{array}{l}\text { : Tidak ada indikasi } \\
\text { penggunaan antibiotik }\end{array}$ \\
\hline Kategori VI & $\begin{array}{l}\text { Data rekam medis tidak } \\
\text { lengkap dan tidak dapat } \\
\text { dievaluasi }\end{array}$ \\
\hline
\end{tabular}

\section{PEMBAHASAN}

Berdasarkan jenis kelamin, pasien perempuan lebih banyak dibandingkan pasien laki-laki yang terdiagnosis demam tifoid di RS X. Hal ini dikarenakan berdasarkan daya tahan tubuh, perempuan lebih berpeluang untuk terkena dampak yang lebih berat atau mendapat mendapat komplikai dari tifoid (Dewi, 2018). Hasil penelitian ini sama dengan hasi penelitian yang dilakukan Toluli (2017) bahwa lebih banyak perempuan yang terkena penyakit demam tifoid dari pada laki- laki karena kekebalan tubuh perempuan lebih rendah dari pada laki-laki sehingga lebih rentan terkena penyakit infeksi seperti demam tifoid.

Berdasarkan usia bahwa pasien yang paling banyak terdiagnosa demam tifoid adalah usia 17-25 tahun berjumlah 37 (51\%) sampel. Hal ini disebabkan karena pada usia ini aktifitas yang dilakukan individu lebih banyak dan pada masa ini sering membeli makanan diluar sehingga faktor resiko untuk terinfeksi bakteri Salmonella thypi lebih besar. Basil Salmonella thypi menular ke manusia melalui makanan dan minuman yang dikonsumsi (Kemenkes, 2006).

Pada tabel 2 dapat dilihat bahwa seftriaxone merupakan jenis antibiotik yang memiliki persentase tertinggi pada penelitian ini sebanyak $90 \%$. Ceftriaxone mempunyai mekanisme menghambat sintesis protein sel mikroba tidak menganggu sel manusia bakteri spektrum luas, penetrasi jaringan cukup baik, dan resistensi kuman masih terbatas. (Sandika dan Suwandi, 2017). Rute pemberian antibiotik merupakan salah satu faktor yang dapat menentukan ketepatan penggunaan antibiotik. Rute pemberian yang paling banyak digunakan yaitu secara parenteral sebanyak (97\%) dikarena efek obat yang sangat cepat dan bioavailabilitas obat mencapai $100 \%$ (Pharmacoterapy Handbook, 2012).

Berdasarkan tabel 3 hasil evaluasi penggunaan antibiotik dengan metode Gyssens diperoleh bahwa dari 72 peresepan antibiotik untuk terapi tifoid sebanyak $90 \%$ peresepan antibiotik yang tergolong penggunaan rasional (kategori 0) . Penggunaan antibiotik yang tidak rasional adalah pada kategori IIIB sebanyak 6\% dikarenakan terdapat peresepan antibiotik yang durasi penggunaannya terlalu singkat dari pedoman penggunaan antibiotik karena ketiga antibiotik pada penelitian ini merupakan terapi empiris sehingga penggunaannya direkomendasikan 2-3 hari (Kemenkes RI, 2011). Hal ini juga mempengaruhi hasil evaluasi pada kategori IVA sebesar $3.7 \%$. Penggunaan antibiotik yang tergolong kategon IVA ditujukan pada penggunaan cefepime dan cefixime dikatakan pemilihan antibiotik kurang efektif dikarenakan jika alergi pada ceftriaxone harus diberikan antibiotik golongan yang berbeda. Menurut penelitian pola penggunaan antibiotik pada pasien dewasa dengan demam tifoid disalah satu RSUP Denpasar (2019) golongan kloramfenikol yang dinyatakan sebagai obat lini pertama tidak lagi digunakan sebagai obat lini pertama karena berkaitan erat dengan tingginya tingkat kekambuhan dan efek samping yang ditimbulkan. 
Karena tingginya MDR atau Multi Drug Resistence menyebabkan perawatan demam tifoid dengan menggunakan antibiotika pada lini kedua seperti fluorokuinolon atau sefaloporin yang sangat disarankan, sehingga golongan fluorokuinolon seperti levofloxacin dianggap optimal untuk pengobatan demam tifoid pada orang dewasa yang memiliki alergi terhadap obat golongan sefalosporin. Penggunaan levofloxacin dipilih karena levofloxacin merupakan antibiotika golongan fluorokuinolon generasi III yang memiliki sprektum luas yang efektif melawan bakteri gram negatif dan gram positif.

Hal ini agak sedikit berbeda dengan penelitian Hapsari, T.N. (2019), yaitu uji evaluasi penggunaan antibiotik pada pasien demam tifoid di instalasi rawat inap RSUD DR. R. Soetijono Blora, hasilnya adalah jenis antibiotik yang digunakan adalah Seftriakson (45,24\%), Klorampenikol $(23,81 \%)$, Siprofloksasin (9,52\%), Sefotaksim dan Ampisislin masing-masing (7,14\%), Kotrimoksasol (4,76\%), dan Azitromisin (2,38\%). Hasil evaluasi penggunaan antibiotik dengan menggunakan metode 4T didapatkan hasil tepat indikasi $100 \%$, tepat pasien $100 \%$, tepat obat $97,62 \%$ dan tepat dosis $36,58 \%$.

Berbeda juga dengan hasil dari Megawati, F (2015), yaitu persentase kerasionalan penggunaan antibiotik pada pasien demam tifoid anak di instalasi rawat inap rumah sakit tk.II Udayana sebesar $30,00 \%$.

\section{KESIMPULAN}

Berdasarkan hasil evaluasi kualitas penggunaan antibiotik dengan metode Gyssens, pemberian antibiotik di instalasi rawat inap RS $X$ periode JanuariDesember tahun 2020. terbanyak $90 \%$ termasuk dalam kategori 0 yaitu penggunaan antibiotik yang rasional. Sebanyak $10 \%$ lainnya termasuk ke dalam penggunaan antibiotik tidak rasional (kategori I-VI) yaitu oleh ada kategori IIIB yaitu penggunaan antibiotik terlalu singkat sebanyak 6,25\% \%, kemudian ada antibiotik lain yang lebih efektif pada kategori IVA sebanyak 3,75\%.

\section{SARAN}

Disarankan untuk melakukan penelitian lanjutan dengan metode penelitian yang lebih variatif, dan aspek yang lebih luas.

\section{DAFTAR PUSTAKA}

Dewi LA. 2018. Evaluasi Penggunaan Antibiotikk Pada Pasien Demam Tifoid Rawat Inap Di Rumah Sakit Islam Klaten Tahun 2017. Skripsi. Fakultas Farmasi Universitas Setia Budi Surakarta.

Friambodo, B., Purnomo, Y., dan Dewi, R, A. 2017. Efek Kombinasi Amoksisilin dan Kloramfenikol Terhadap Pertumbuhan Bakteri Salmonella Typhi. Journal of Islamic Medicine. Universitas Islam Malang.

Gyssens, I, C. 2005. Audit for Monitoring the Quality of Antimicrobial Prescription in Hospital, Clinical Microbiology Infeection, 7(6) : 12-15.

Hadi, M. 2009. Biologi Insecta Entomologi. Yogyakarta : Graha Ilmu. Hidayati, P. Dkk. 2015. Rasionalitas Penggunaan Antibiotik Pada Kasus Demam Tifoid Anak Di Rumas Sakit Bethesda Serukam Bengkayang Periode Januari 2013-Desember 2015. Jurnal. Universitas Tanjungpura : Pontianak.

Hapsari, T.N. 2019. Uji evaluasi penggunaan antibiotik pada pasien demam tifoid di instalasi rawat inap RSUD DR. R. Soetijono Blora periode Januari 2017- Agustus 2018. Fakultas Farmasi Universitas Muhammadiyah Surakarta.

Idrus, H. H. 2020. Buku Demam Tifoid. Universitas Muslim Indonesia : Makassar.

Kemenkes. 2006. Keputusan Menteri Kesehatan Republik Indonesia 
No.364/MENKES/SK/V/2006 tentang Pedoman Pengendalian Demam Tifoid., Jakarta. Depdiknas.

Kemenkes RI. 2011. Modul Pelatihan Penggunaan Obat Rasional. Jakarta. Kemenkes RI.

Kemenkes RI. 2018. Revisi Rencana Aksi Kegiatan (RAK). Jakarta. Kemenkes RI.

Kusumastuti, S. 2017. Rancang Bangun Alat Aktivitas Pasien Bed Rest. Orbith, 13(1)

Megawati, F., 2015. Persentase Kerasional an Penggunaan Antibiotik Pada Pasien Demam Tifoid Anak Di Instalasi Rawat Inap Rumah Sakit Tk.II Udayana Denpasar. Jurnal Ilmiah Medicamento 1(1) 2015; 26-32

Musnelina, L. Dkk. 2004. Analisis Efektivitas Biaya Demam Tifoid Anak Menggunakan Kloramfenikol dan Seftriakson di Rumah Sakit Fatmawati Jakarta Tahun 2001-2002. Universitas Indonesia : Jakarta.

Nuraini, F. A., Garna, H. \& Respati, T. 2015. Perbandingan Kloramfenikol dengan Seftriakson terhadap Lama Hari Turun Demam pada Anak Demam Tifoid. Prosiding Pendidikan Dokter, 0(0), 914-919.

Notoatmodjo. 2014. Metodologi Penelitian Kesehatan Edisi Revisi. Jakarta. Rineka Cipta.

Paul, U, K \& Bandyopadhyay, A. 2017. Typhoid fever : a review. International Journal of Advances in Medicine, 4(2), 300-306.

Permenkes. 2019. Pendayagunaan Dokter Spesialis. Peraturan Menteri Kesehatan Republik Indonesia Nomor 36.

Permenkes. 2015. Program Pengandalian Resistensi Antimikroba di Rumah Sakit. Peraturan Menteri Kesehatan Republik Indonesia Nomor 8.

Prasetya, I. P. D. 2017. Evaluasi Rasionalitas Penggunaan Antibiotik Pasien Demam Tifoid di Instalasi Rawat Inap Rumah Sakit Panti Rini Yogyakarta Periode Tahun 2015-2016.
Jurnal. Universitas Sanata Dharma : Yogyakarta.

Rufaie, J. R. 2021. Evaluasi Rasionalitas Pengggunaan Antibiotik pada Pasien Demam Tifoid Rawat Inap di RSU Universitas Muhammadiyah Malang Tahun 2019. Jurnal. Universitas Islam Negeri Maulana Malik Ibrahim : Malang.

Sakinah dan Indria, A. 2016. Tata Laksana Demam Tifoid Tanpa Komplikasi pada Anak. Sari Pediatri Local Journal, 14(5):271-6.

Sandika, J. Dan Suwandi, F.J. 2017. Sensitivitas Salmonella Typhi Penyebab Demam Tifoid Terhadap Beberapa Antibiotik. Majority Jurnal Kedokteran, 6(1).

Soedarmo, P., Garna, H., Hadinegoro, S. R. S., Satari, H. I. 2015. Buku Ajar Infeksi dan Pediatri Tropis. 2nd ed. Jakartas : Badan Penerbit IDAI.

Sugiyono. 2007. Metode Penelitian Kuantitatif Kualitatif dan R\&D. Bandung. Alfabeta.

Sukmawati, I. Dan Jaya, M. 2020. Evaluasi Penggunaan Antibiotik pada Pasien Tifoid Rawat Inap di Salah Satu Rumah Sakit Pemerintah Provinsi Bali dengan Metod Gyssens dan ATC/DDD. Jurnal Farmasi Udayana, Vol 9, No 1 : 37-44.

Tandi, Joni. 2017. Kajian Kerasionalan Peenggunaan Obat Pada Kasus Demam Tifoid di Instalasi Rawat Inap Anutapura Palu. Jurnal Ilmiah Pharmacon, 6(4). ISSN 2302-2493. STIFA Pelita Mas Palu : Sulawesi Tengah.

Upadhyay, Rajesh., Nadkar., Milind, Y., et al. 2015. API Recommendations For the Management of Typhoid Fever. Jurnal of The Association of Phyicians of India, 63. 